\title{
The Contributions of Gamma Probe to Lesion Detectability and Surgical Safety in Recurrent Thyroid Cancer at Risk
}

\author{
Risk Altındaki Nüks Tiroid Kanserinde Gama Probun Cerrahi Güvenliğe ve Lezyon \\ Seçilebilirliğine Katkıları
}

\author{
Salih Sinan Gültekin1, Güleser Saylam², Tuncay Delibaşı , Hakan Korkmaz² \\ IDışkapı Yıldırım Beyazıt Training and Research Hospital, Division of Nuclear Medicine, Ankara, Turkey \\ 2Dışkapı Yıldırım Beyazıt Training and Research Hospital, Department of Otolaryngology-Head and Neck Surgery, Ankara, Turkey \\ 3Dışkapı Yıldırım Beyazıt Training and Research Hospital, Department of Endocrinology and Metabolism, Ankara, Turkey
}

\begin{abstract}
In patients, who underwent thyroid surgery or treated with $1-131$ radioiodine previously for differentiated thyroid cancer, a second surgical intervention carries higher risks due to distortion of the natural anatomy and development of fibrotic/cicatricial tissue. In addition, accurate assessment of current status about extent of the disease is important in terms of success of the surgery. In this case report, we present the positive contribution of intraoperative gamma probe used for lesion detectability and for surgical safety in a patient operated for several times and administered high cumulative dose of radioiodine therapy for diffentiated thyroid carcinoma previously.
\end{abstract}

Key words: Technetium Tc 99m Sestamibi, thyroidectomy, local neoplasm recurrence, thyroid cancer, Scintillation Counting

\section{Özet}

Daha önceden tiroid cerrahisi geçiren veya I-131 radyoiyot tedavisi uygulanan differansiye tiroid kanserli hastalarda uygulanacak olan ikinci bir cerrahi müdahale doğal anatominin bozulması ve fibrotik yada skatrisyel dokuların gelişimi nedeniyle daha fazla riski taşır. Ayrıca, hastalığın yaygınlığı hakkındaki mevcut durumun doğru bir şekilde değerlendirilmiş olması da cerrahi başarı açısından oldukça önemlidir. Biz bu olgu sunumunda, differansiye tiroid kanseri için birkaç kez tiroid cerrahisi geçiren ve kümülatif yüksek doz radyoiyot tedavisi uygulanan bir olguda intraoperatif gama prob kullanımının lezyon deteksiyonu ve cerrahinin güvenliği açısından sağladığı olumlu katkıyı sunmaktayız.

Anahtar kelimeler: Teknesyum Tc 99m Sestamibi, tiroidektomi, lokal neoplazm rekürrensi, tiroid kanseri, sintilasyon sayımı

\section{Introduction}

Differentiated thyroid cancer (DTC) usually has a good prognosis following an appropriate initial treatment (1). Loco-regional recurrence can occur in $20 \%$ of treated DTC patients in the follow-up period (2). The main treatment modality is surgery but a protocol combining radioiodine therapy and surgery is often applied. Loss of 131 I-radioiodine avidity can be seen in patients who have been treated with repeated applications of the 131 -radioiodine therapy (RIT).
Neck ultrasonography (US), 99mTc-methoxyisobutylisonitrile (99mTc-MIBI) and 18F-fluorodeoxyglocose (18F-FDG) scans and intraoperative gamma probe (GP) are shown to be useful in such patients in varying proportions $(3,4,5,6,7)$. The accurate identification of recurrent tumor tissues may be compromised after repeated operations. Surgical GP technique has some potential advantages and it may offer some benefits in the previously operated neck regions $(8,9,10)$. In a comparative way with other imaging methods, we present several contributions of intraoperative gamma

Address for Correspondence: Salih Sinan Gültekin MD, Dışkapı Yıldırım Beyazıt Training and Research Hospital, Division of Nuclear Medicine, Ankara, Turkey Phone: +90 31232600 10/1274 E-mail: gultekinsinan@gmail.com Received: 02.06.2012 Accepted: 26.11.2012

23. Ulusal Nükleer Tıp Kongresi, 27 Nisan - 01 Mayıs 2011, Izmir, Türkiye 
probe method for lesion detectability and about surgical safety in a patient with recurrent thyroid carcinoma whose reoperation is risky because of previous applications.

\section{Case Report}

A 54-year-old male patient with DTC, had a history of multiple of thyroid and neck operations with repetitive RIT (total $37 \mathrm{GBq}$ ) during the 15-year follow-up period in other centers. After the last RIT, whole-body scan was normal but he underwent left limited neck dissection for suspicious fine-needle cytology and histopathological examination revealed papillary carcinoma metastases. Then he applied to our center; he was under L-thyroxine suppression therapy, serum thyroglobulin, antithyroglobulin-antibody and thyroid stimulating hormone (TSH) levels were, 21.53 $\mathrm{ng} / \mathrm{mL}, 57 \mathrm{U} / \mathrm{mL}$ and $<0.003 \mathrm{ulU} / \mathrm{mL}$, respectively. The neck US revealed lesions with dimensions of $14 \times 14 \times 17 \mathrm{~mm}$ in right thyroid bed, $10 \times 10 \times 15 \mathrm{~mm}$ in left thyroid bed and a lymph node with dimensions of $6 \times 10 \times 10 \mathrm{~mm}$ in left cervical region. A 99mTc-MIBI scan revealed three pathological foci in the thyroid bed (Figure 1), 18F-FDG positron emission tomography-computed tomography (PET-CT) scan revealed increased uptakes in right thyroid bed (SUV $\max : 12.5)$, left

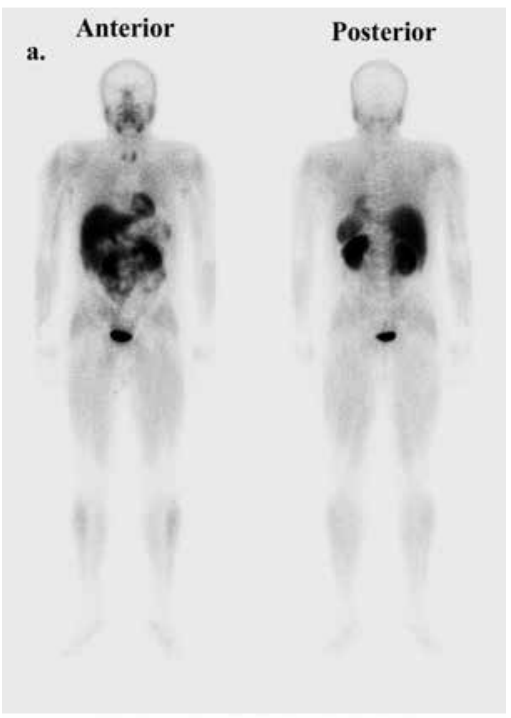

b.

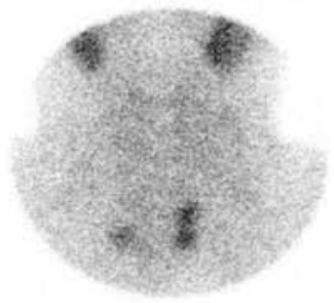

Figure 1. Preoperative $99 \mathrm{mTC-MIBI}$ whole body scan (a) and neck pinhole image (b) show pathological uptakes in a focus in the right thyroid bed and two foci in the left thyroid bed.

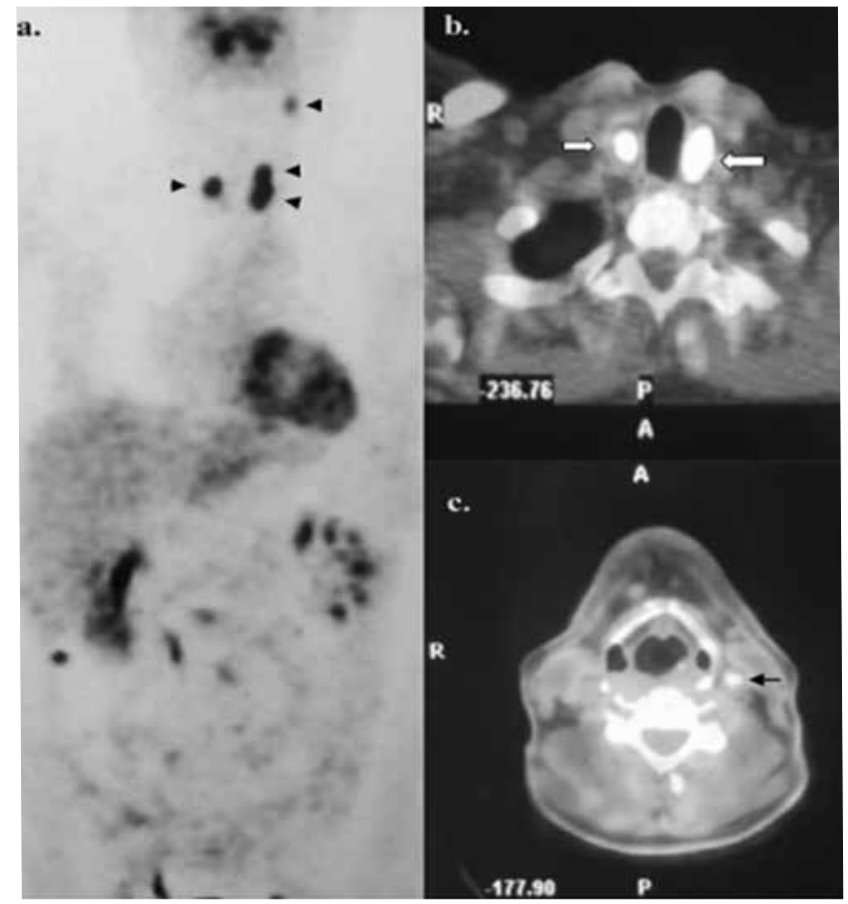

Figure 2. Preoperative 18 F-FDG whole-body PET (a) and axial PET-CT fusion (b, c) images show pathological uptakes (arrowsheads) in both thyroid beds (white arrows) and a left jugular lymph node (black arrow).

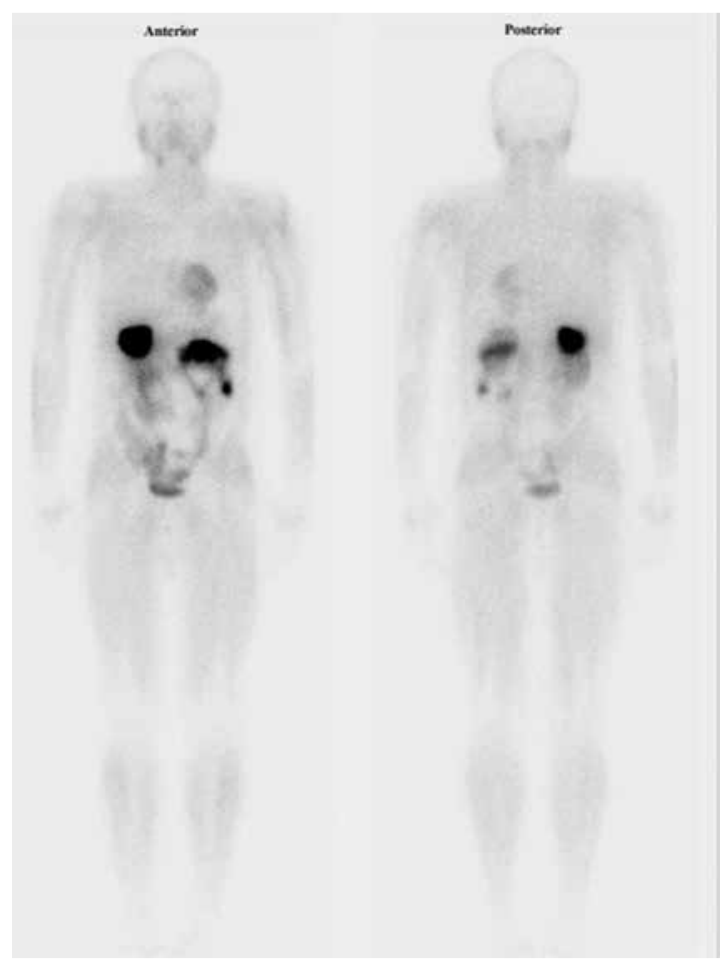

Figure 3. Postoperative $99 \mathrm{mTC}-\mathrm{MIBI}$ whole body scan shows that there is not any pathological uptake and physiological radiotracer distribution is observed. 
thyroid bed (SUV max: 14.8) and in a left jugular lymph node (SUV max: 6.0) (Figure 2).

The decision for treatment was re-operation of the patient with the surgical gamma probe guidance. Ten minutes before incision, $37 \mathrm{MBq}$ of 99mTc-MIBI was injected intravenously. The exploration was difficult due to dense fibrosis of the surgical field and anatomical distortions. Bilaterally recurrent laryngeal nerves were identified and preserved, but parathyroid glands were not encountered. Radioactivity counts were collected intraoperatively with a surgical GP (Europrobe III, Eurorad, France) for background (BG), and hot spots which indicated the pathological lesion (L). GP counts revealed five hot spots; on the right thyroid bed (L/BG: 3.3), on the left thyroid bed (L/BG: 4.4 and 3.8), on the left cervical level 2 (L/BG: 3.6 ) and level 3 (L/BG: 3.2). There was a statistically significant difference between mean L/BG values before excision (3.66 \pm 0.48$)$ and after excision (1.40 \pm 0.27$)$. All condemned tissues were removed completely, and the postoperative period was uneventful. The patient was discharged next day with mobile cords and normal calcium level. Histopathological examination revealed papillary carcinoma foci in both thyroid beds $(>10$ $\mathrm{mm})$, two conglomerate metastatic lymph nodes in left thyroid bed $(>10 \mathrm{~mm})$, and two metastatic lymph nodes at the level 2 and $3(<10 \mathrm{~mm})$. When the patient was controlled on the eight months after the surgery, $99 \mathrm{mTc}$ MIBI scan (Figure 3) and chest CT findings were normal, serum $\mathrm{Tg}$ and TSH levels were $6.30 \mathrm{ng} / \mathrm{ml}$ and $0.02 \mathrm{ulU} /$ $\mathrm{mL}$, respectively.

\section{Literature Review and Discussion}

Local-regional recurrences may develop in up to $20 \%$ of patients with DTC. They are also associated with a reduction in survival and an increase in mortality in some series $(2,3)$. Although recurrence usually occurs during the early follow-up period, it can also rarely occur later in the follow-up as seen in our case. When the lymph node recurrences are located in central compartment, or behind the vascular structures, or small in size; they may not be palpable and usually diagnosed with the combination of elevated serum Tg levels and neck US $(3,11)$.

Loss of 131|-radioiodine avidity by metastatic thyroid cells may develop as a result of progressive tumor dedifferentiation (6). This can be partly explained by a decrease in sodium iodide symporter expression after RITs. Although conventional 131|-radioiodine applications become useless, serum $\mathrm{Tg}$ levels can still be a useful marker in such DTC patients, because it reflects different cellular mechanisms $(6,7)$. When loco-regional recurrence is detected in patients with elevated Tg levels and negative 131/-radioiodine scan, accurate diagnosis of localization and spread of the disease is crucial and US, $99 \mathrm{mTC}-\mathrm{MIBI}$ and 18F-FDG PET-CT scans preoperatively and radioguided surgery intraoperatively might be helpful for this purpose
$(4-7,12)$. Casara et al. (4) found a good sensitivity for $99 \mathrm{mTC}$-MIBI scan $(94,1 \%)$ and neck US $(90,2 \%)$ in the determination of cervical lymph node metastases from DTC. On the other hand, Rubello et al (7) showed that only $58 \%$ of the foci identified by a pre-operative $99 \mathrm{mTC}-\mathrm{MIBI}$ scan were metastatic. Rubello et al. (6) emphasized that all lesions seen in high-resolution US were also identified with GP-guided surgery. Nahas et al (12) obtained sensitivity of only $66 \%$ but with a high specificity and positive predictive value $(100 \%)$ when they evaluated the impact of $18 \mathrm{~F}-\mathrm{FDG}$ PET-CT in 33 patients with suspected recurrent papillary thyroid cancer. In another study by Razfar et al. (5), they found a sensitivity of $80.7 \%$, specificity of $88.9 \%$, positive predictive value of $94.7 \%$ for 18 F-FDG PET-CT scan in the setting of recurrent disease from DTC in 125 patients. The surgery is the treatment of choice but re-operation has its own inherent technical difficulties because of previous surgical interventions (8). Success rate of re-operation may decline due to the distortion of natural anatomical structures, development of fibrotic/scatrical tissues and decreased volume of residual or metastatic tissues. Thus, intraoperative quick labeling and correct identification of functional tissues with an appropriate radiotracer can be helpful. Radioguided surgery was assessed very useful in $14 / 58$ patients, useful in 22/58 patients, moderately useful in $17 / 58$ patients and not useful in $5 / 58$ patients in the study of Rubello et al (7).

We used intraoperative GP technique with low dose $99 \mathrm{mTC}-\mathrm{MIBI}$ (13) in a patient with history of multiple thyroid surgeries and high dose RIT. $99 \mathrm{mTc}-\mathrm{MIBI}$ is a radiopharmaceutical with convenient specifications such as; easy access, low cost and high counting statistics. Utilization of low dose protocol provides considerably reduced radiation dose received by the fingers of the surgeon. Use of the same radiopharmaceutical in the preoperative and intraoperative assessment supports reliability and confirmation of the findings. Serum Tg levels usually decrease after removal of tumoral or remnant tissues. A 1 or $2 \mathrm{ng} / \mathrm{ml} \mathrm{Tg}$ cutoff value can be used for the follow-up of disease-free status in the post-operative period. Rubello et al (7) found that there were normal serum $\mathrm{Tg}$ levels $(<2 \mathrm{ng} / \mathrm{ml})$ in $43 / 58$ patients, slightly high Tg levels $(<10 \mathrm{ng} / \mathrm{ml})$ in $12 / 58$ patients and extremely high $\mathrm{Tg}$ levels in 3/58 patients, within the mean follow-up of approximately 30 months. In our patient in the eighth month after surgery, serum Tg level was $6.30 \mathrm{ng} / \mathrm{ml}$ and there was no evidence of metastatic disease on the imaging studies. This condition was considered in accordance with presence of microscopic disease.

In conclusion, with surgical GP technique, recurrent/ residual neoplastic thyroid tissues had been removed with high precision without any complications in a technically 
difficult surgical field. Additionally, on the basis of histopathological evaluation we observed that GP method with low dose $99 \mathrm{mTC}-\mathrm{MIBI}$ contributed to preoperative studies for lesion detectability by determining an additional occult lymph node metastases.

\section{References}

1. Mazzaferri EL, Kloos RT. Clinical review 128: Current approaches to primary therapy for papillary and follicular thyroid cancer. J Clin Endocrinol Metab 2001;86:1447-1463.

2. Hay ID, Thompson GB, Grant CS, Bergstralh EJ, Dvorak CE, Gorman CA, Maurer MS, Mclver B, Mullan BP, Oberg AL, Powell CC, van Heerden JA, Goellner JR. Papillary thyroid carcinoma managed at the Mayo Clinic during six decades (1940-1999): temporal trends in initial therapy and long-term outcome in 2444 consecutively treated patients. World J Surg 2002;26:879-885.

3. Haber RS. Role of ultrasonography in the diagnosis and management of thyroid cancer. Endocr Pract 2000;6:396-400.

4. Casara D, Rubello D, Saladini G, Mazzarotto R, Sotti G, Tomasella G, Pelizzo MR. Clinical approach in patients with differentiated thyroid carcinoma and negative 1311 whole body scintigraphy: importance of $99 \mathrm{mTc}-\mathrm{MIBI}$ scan combined with high resolution neck ultrasonography. Tumori 1999;85:122-127.

5. Razfar A, Branstetter BF 4th, Christopoulos A, Lebeau SO, Hodak $\mathrm{SP}$, Heron DE, Escott EJ, Ferris RL. Clinical usefulness of positron emission tomography-computed tomography in recurrent thyroid carcinoma. Arch Otolaryngol Head Neck Surg 2010;136:120-125.

6. Rubello D, Pelizzo MR, Casara D, Piotto A, Toniato A, Fig L, Gross M. Radio-guided surgery for non-131l-avid thyroid cancer. Thyroid 2006;16:1105-1111.
7. Rubello D, Salvatori M, Casara D, Piotto A, Toniato A, Gross MD, AlNahhas A, Muzzio PC, Pelizzo MR. 99mTc-sestamibi radio-guided surgery of loco-regional 131 lodine-negative recurrent thyroid cancer. Eur J Surg Oncol 2007;33:902-926.

8. Aras G, Gültekin SS, Küçük NO, Demirer S, Tuğ T. Intraoperative gamma probe guidance with $99 \mathrm{mTc}$-pertechnetate in the completion thyroidectomy. Ann Nucl Med 2009;23:421-426.

9. Terzioğlu T, Senyurek YG, Tunca $F$, Türkmen C, Mudun A, Salmaslıoglu A, Sanlı S, Bircan H, Demirkol O, Tezelman S. Excision efficiency of radioguided occult lesion localization in reoperative thyroid and parathyroid surgery. Thyroid 2010;20:1271-1278.

10. Ilgan $S$, Oztürk E, Yildiz R, Emer $O$, Ayan A, Görgülü $S$, Alagöz $E$, Deveci S, Ozgüven MA, Tufan T. Combination of preoperative ultrasonographic mapping and radioguided occult lesion localization in patients with locally recurrent/persistent papillary thyroid carcinoma: a practical method for central compartment reoperations. Clin Nucl Med 2010;35:847-852.

11. Schlumberger $M$, Pacini $F$, Wiersinga WM, Toft $A$, Smit JW, Sanchez Franco F, Lind P, Limbert E, Jarzab B, Jamar F, Duntas L, Cohen O, Berg G. Follow-up and management of differentiated thyroid carcinoma: a European perspective in clinical practice. Eur J Endocrinol 2004;151:539-548.

12. Nahas Z, Goldenberg D, Fakhry C, Ewertz M, Zeiger M, Ladenson PW, Wahl R, Tufano RP. The role of positron emission tomography/ computed tomography in the management of recurrent papillary thyroid carcinoma. Laryngoscope 2005;115:237-243.

13. Rubello D, Salvatori M, Pelizzo MR, Rampin L, Fanti S, Gregianin M, Mariani G. Radio-guided surgery of differentiated thyroid cancer using (131)l or 99mTc-Sestamibi. Nucl Med Commun 2006;27:1-4. 